H.O. Verbivska, Student, Master's Degree, Faculty of Philosophy

Taras Shevchenko National University of Kyiv,

60, Volodymyrska Street, Kyiv, 01033, Ukraine

\title{
AESTHETICAL EXPERIENCE AS PATHOLOGICAL DISCOURSES OF ABJECTION AND MELANCHOLIA IN THE BEKSINSKI' ART
}

\begin{abstract}
This article tackles the issue of aesthetic experience from the pathologized everyday discourse viewpoint in the system of relations between I and symbolic order, where transgressed and close to symbolic death I is predominant. The stage, in which I, crossing the symbolic borders, stay readable, appears to be the process of continuous constituting the aesthetic experience and its transforming into the primordial a priori structure of everyday discourse.

The problem lies deeply in the preserving of evanescent borders which are said to exist in the cultural palpability and simultaneously to be exiled from the system. The article exemplifies pathological discourses by referring to the Beksinski' works, namely his numerous ways of articulating the ineffable. However, articulated ineffable, similarly to such culturally conditioned reactions as abjection and melancholia, declares double death of the discursive subject: the first time when the separation from primordial presymbolic world takes place and the second time during problematizing the symbolic borders and paradoxical immortalization concerning postulated frontiers. The aim of this article is to dig out kaleidoscope of images and sub-images from Beksinski' works through the motive of crucifixion resulting in the specific value of Christ's body and chimerical things inside the dehumanized catastrophic space. It is demonstrated how pathological discourse of melancholia could be intertwined with the discourse of abjection in the common point of transgressing the limits, making the symbolic space full of details indicating the risk of Ego being disintegrated, staying inside the transgressed limits as constituting aesthetical experience. Inexplicability of terrible post-apocalyptic world is readable via symbolic coordinates insofar as the main primal object (the body of Christ) occurs to be banished. Appearing of aesthetic experience is paralleled to the stages of psychosexual development in the existence of symbolic being where in opposition to classical freudism maternal authority is accentuated. That's how Kristevan style of psychoanalytic ruminations looks like.
\end{abstract}

Key words: pathological discourse, prime object, symbolic system, autonomized syncreticity, separated Ego, preoedipal world.

удК 130.2

I. V. Zhyvohliadova, Ph.D., Assosiate Professor Taras Shevchenko National University of Kyiv, 60, Volodymyrska Street, Kyiv, 01033, Ukraine irinavictz@gmail.com

\section{RESEARCH PERSPECTIVES OF THE CULTURAL EXPERTISE IN THE CONTEXT OF FORMATION OF THE URBAN CULTURAL SPACE}

The article analyzes the spectrum of objects and problems in the context of the cultural space of the city that may (and need) be the subject of attention of expert activities in the field of culture. The issue of culturological expert knowledge is considered in the context of the process of optimizing the use of the urban cultural capital, removing restrictions on access to its resources, and creating tools to struggle with the "business-colonization of culture". It is argued that cultural expertize can become a transversal mechanism and a tool of finding the optimal analytical assessment of the relationships, their intersections, deep structures, all kinds of chronotopes that are inherent in the modern city.

Key words: cultural expertise, cultural space of the city (urban cultural space), modern visual practices, cultural capital.

Formulation of the problem. The analysis of the processes taking place in the modern city shows that there is a deep imbalance not only between the interests of the present and future generations, but also within the generations themselves. These problems of the city shoe the urgency of dramatic changes in the system and models of production and consumption of cultural products. The imbalance in the ability of the citizens to create and consume a quality cultural product is no less a serious threat to the city than climate change, environmental pollution and urban mobility problems. In addition, there was a situation where "a person no longer knows what he wants ... he becomes alienated, subjected to manipulation and mystification" [3, p. 209].

The sociocultural space at the present stage of its development, with the characteristic complication of value self-identification of both a particular individual and social groups, the possibilities of their understanding and interaction, actualize the special humanitarian analytics. The diversity of socio-cultural practices has led to a corresponding diversity of expertise. Its need is determined by the well-known situation of devaluation, the complexity and controversy of those transformations that take place in modern Ukrainian society. The need to deepen and "modernize" the methodological basis of humanitarian expertise is becoming apparent. If we talk about relevant expert practice in science, art, politics, we have accumulated considerable experience. But there is a lack of systematic research on those problems of expert technologies, that are based on a comprehensive knowledge of socio-cultural reality, would allow to exist effectively and responsible in different forms and at different levels of cultural creation.

Dynamization of transformational processes that take place in modern society and, as a result, the formation of prefigurative culture, fundamentally change the communicative system of exchange of experience, the logic of information continuity. As a result, the previous experience (both own, personal, and gained by previous generations) ceases to be indisputably valuable to the following actors - creators of the cultural space of the city. Therefore, there is an urgent need for objective peer review. In addition, the reason for this is, unfortunately, unproductive use of resources of urban culture, indifference to their value.

The interaction of the spatial composition of the city, its elements, design forms, historical and architectural context is not only a need for the development of scientific and theoretical discourse. Urban space planning, its various elements of the landscape is visualized in the integral face of the city, which, in turn, is the part of the picture of the world that citizens have. If a city is viewed as a complex multifunctional open system with a number of constantly updated (up-to-date) problems, it is not possible to solve these problems without providing objective, knowledgebased information during any intervention in the urban spatial environment, about the "human factor", how much these changes, responding to the needs and ideas about the comfortable life of new residents of the city affect the value quality of this life, how new technologies not only work for economic efficiency, for creating favorable conditions for business, but also are correlated, as a 
harmonious element, with the interests of human development in the long perspective. In the current conditions of society development, cultural expertise is a representative of the social demand for cultural knowledge.

Analysis of research and publications. City as the object of study provides the complexity of the systematization of the relevant knowledge. This allows, taking into account all aspects of the functioning and development of urban culture, the tendencies of postindustrial civilization, to focus on their humanistic vector, to take into account the human factor. Representatives from the various fields of research have accumulated a big amount of the research material that testifies to the many issues of human development, interaction and communication that are constantly open to new answers.

Aesthetic and cultural problems of functioning of urban space are investigated in the works of V. Glazichev, A. Ikonnikov, A. Marder, Y. Mukarzhovsky, E. Orlova, M. Reimers, L. Strigaleva, O. Fomenko, N. Shebek, V. Shymko, O. Shvidkovsky, Ya. Yuryk, Z. Yargina. The language of urban space is analyzed by $P$. Weil, U. Eko, Y. Lotman, V. Toporov. Specifics of cultural personality (urban, regional, national) are devoted to the works of M. Antsiferov, G. Kaganov, G. Zimmel, L. Salmon, $\mathrm{N}$. Mednis. Issues of urban environment design, design as a socio-cultural phenomenon are explored by $\mathrm{V}$. Aaron, R. Baker, B. Burdek, L. Zhadov, M. Kagan, E. Koryagin, Y. Nazarov, P. Spark, F. Fischer, G. Shchedrovitsky.

Visual practices of organizing the perception of the urban environment, its semantics are the subject of research by R. Arnheim, I. Artamonov, S. Vavilov, R. Gregory, D. Gregg, J. Gibson, V. Zinchenko, E. Klimov, K. Lynch, A. Moles, S. Khasiyev,

The study of the phenomenon of expert knowledge, its cultural component, is based on an interdisciplinary approach. The analysis of expert activity, its peculiarities, determination of the place of cultural studies and philosophy in modern expert practice, in particular in the sphere of protection of cultural heritage and cultural values is carried out in the works of N. Krivich, V. Panchenko, O. Sungurov, G. Tulchynsky. The content and functions of philosophical, anthropological, ethical expertise are analyzed in the works of S. Goncharov, L. Nikiforova, M. Uvarov. Expert support of legislative and rule-making activity in the field of cultural policy, experience of expert activity in the field of cultural heritage protection are considered by $\mathrm{T}$. Antipova, T. Gudyma, L. Gumenyuk, Y. Izbachkov.

The separate, especially demanded by modern society, area, that requires serious expert work, is the creation of information space of the city, as well as - image support of the authorities, their separate bodies (research by A. Suvorova, T. Shmelev, S. Shaykhitdinova). Examination of research products, as well as the processes and results of educational activities, problems of criteria for assessing the quality of scientific texts and cultural education are analyzed by V. Yegorkin, N. Krivich, L. Mosolova, L. Nikiforova, S. Tikhomirov, T. Sholomova.

Purpose of the article is to cover a spectrum of objects and problems in the context of the formation of the urban cultural space that may (and need) to be the focus of the cultural expertise.

Exposition of the main material of the study. The entry of civilizational humanity into the post-industrial stage of development has given rise to many challenges for the modern city, on which its vitality and self-progression depend. To paraphrase the famous expression of V. Churchill, we can say that humanity first created the city, and then it created the humanity.
Indeed, the problem of coexistence of different cultural spaces, tensions, even conflict of which is increasing, remains urgent for the modern city. Within each space a dominant style of consumption of culture, habits, certain types of cultural practices are concentrated, and the characteristic perception of transformations take place in the city. The urban suburbs and central districts concentrate their collective memory, which is hidden by the aesthetics of everyday life of their inhabitants, by the ways of their self-expression, the need for certain symbolic forms of fixation of cultural experience.

One solution to this conflict of experiences of the creation of a productive way of blurring social and cultural boundaries that is necessary for the interaction of different types of cultures. As example, modern urbanists (E. Amin, E. Hirsch, etc.) offer transformational work with public spaces. First of all, they create the conditions for organizing new connections between media of different types of cultural activities. Now the recreation of old depressed industrial spaces, the creation of ecological parks, educational, cultural centers there is becoming a popular way communication between people of different social and cultural level, which allows not to view the stranger as an enemy, but to interact with him, create new connections. Due to the multiformity of cultural and artistic practices presented in these spaces, new conditions for bringing people of different social and cultural levels who are ready to discover and perceive new things together, to revise their ideas about culture [10], for the emergence of a new culture of communication and interaction of people, "Social correctness" [8, 299], which forms the social cultural environment of the new city, are created.

At the same time, the high level of inequality in various spheres, ranging from gender, income, socio-economical circumsrances to the disproportion in distribution of cultural goods, despite the overall socio-economic progress, directly affects the quality of cultural and social institutions and the level and quality of cohesion of urban society. Ensuring inclusive sustainable urban development is directly linked to the creation of a cultural space in which equal access to socio-economic benefits (education, medicine, employment, natural resources, etc.) coexisted with empowering urban populations to participate directly in the formation of cultural factors that determine their lives, to obtain the necessary experience for life. In addition, "Today it is not about the technology of production of things (as it was in modern times in the period of development of industrial technologies), but the creative technologies of production of people "(Das Man, The Men), their needs, lifestyle, values, which are embodied in the forms of cultural and symbolic products, on the basis of... imagemaking technologies, myth-design, creative marketing, discursive techniques, neurolinguistic programming, reframing and other numerous socio-cultural, multicultural and anthropic technologies "[5].

The contemporary realities of urban life are connected with the activation of a large number of different cultural practices (among which the visual ones remain dominant), which have filled the cultural space of modern cities, especially metropolitan areas. They create a specific information system for the preservation and transformation of cultural and historical memory. The "Memory City" (according to A. Grunbach's statement) [9, p.56] is filled with new actors, new impressions, value ideas, "executive technologies", which are represented in all fragments (material and intangible) of the urban environment along with the objects that record a multidimensional previous experience, its history. Due to this background, the questions are: how does the 
emergence and placement of certain objects contribute to social integration, the inculturation of urban citizens, push them into dialogue and thus break the isolation paths both interpersonal and socio-cultural? How do these actions ensure and intensify the effective functioning of human (= cultural) capital ("knowledge, enlightened part of labor resources, tools of intellectual and managerial work, living and work environment" [6]) as a productive level of urban space development? Are actions driven by temporary mercantile interests that are far from focused on truly improving the quality of life? Are there initiatives that expand the subjectivity of each citizen, expand and enhance his or her cultural choices?

One of the most important issues of the modern city, its cultural space, in which the place of cultural expertise is indisputable, is the problem of urban planning, the ecology of its planning, visual peculiarities in particular. Modern materials, constructions, technologies along with large, often elementary volumes of architectural forms, the incomplete implementation of the architectural plan of the city (if any), the lack of a holistic architectural vision of the visual face of the city are the only tip of the iceberg that creates space alienated from a citizen. All these conditions (the lack of individualization of the whole residential complex, the area, not individual houses, subordination of its parts) are not just technical aspects of the city's construction. Plans for expanding urban space largely ignore the importance of the significant factors of contemporary urban culture, which, in turn, are not merely the artistic part of a small creative part of the inhabitants. The absence of a harmonious expressive composition of the city, geometry of space forms of living space is usually an important element of the absence of urban planning, in which there would be a functional division of the territory into zones of business and social activity, relative quiet life, inclusion in the natural environment with the organization of perception environment (light, geometric and other contrasts and additions). Such kind of development of the territory of the city leaves a person in a situation where there is no such level of arrangement of its own territory, where it would not be limited only to an apartment.

The construction and reconstruction of a city should not violate its identity, its own history, which is embodied in historical buildings, natural landscapes. Ultimately, it threatens to impoverish both the city itself and its inhabitants, who fall into an exclusion zone where personal prosperity cannot be achieved, where there is no signsymbolic space in which everyone consider himself a harmonious part of society.

In view of the above, it should be mentioned that, since 1990, since the "Human Development Report", the discourse around it has been fundamentally shifting. The anthropocentric approach became dominant. The emphasis changes from the optimization of economic growth, its diversity, material wealth (although it continues to be an actual and necessary means of human development) to the optimization and diversity of human potential, the entire spectrum of human well-being. The latter provides the growth and enjoyment of citizens' rights and freedoms. In our view, a concept that considers human development both as the ultimate goal of the development of any cultural space, and as "the process of empowering human choice, ... human development through the formation of human potential, carried out by people (through active participation in processes, that shape their lives) and for people (by improving their lives) "[2]," the process of extending people's freedom to live long, healthy and creative lives, to the fulfillment of other goals that they believe are valuable; to take an active part in ensuring justice and sustainability on the planet "[4], gives the opportunity to find the optimal answers to the questions of the need and opportunities of cultural expertise. The interdependence of alternative choices is always obvious to the cultural expert. That is why any initiative is considered by the cultural expert from different points of the view, which relate to opportunities not only to live a long life, but also to live happily, to acquire relevant knowledge. Society needs to answer the questions: how to measure the loss from past cultural practices, products that have not been created, how to compare it, measure the depth of morality, tastes, including taste for quality mental effort, personal "costs" for quality cultural production and consumption? The specificity of cultural expertise is that in addition to identifying the object, its classification, identification, to increase the predictability of the final results of human activity in various areas of life. Not so much the specific phenomena, processes, subject matter as such (this is the competence, for example, of the art sciences) are being estimated, but the effects they produce, their cultural meaning. It is the growth of cultural (human) capital that should be the main criteria for the efficiency of all directions of the modern city development, because it is this capital that is the main source and a necessary condition for this development. Adequate picture of quality in culture involves taking into account the symbolic costs (emotional, psychological, moral, ethical, aesthetic, etc.) of the production and circulation of goods and services in any sphere of construction and existence of urban space.

Ideally, one of the main tasks of the city government is the promotion of cultural enrichment, the development of artistic practices and the issue for the preservation of cultural heritage. Accordingly, there is a problem of determining priority investments (material, informational, etc.) in certain aesthetic, artistic and other innovations. But, unfortunately, the space of the modern city is predominantly shaped in accordance with the economic feasibility and rules of the market, which is becoming increasingly aggressive. Due to the constant migration of the population, products are becoming standardized, unified, there is a demarcation of standards. The quality of a cultural product and the corresponding cultural goods are difficult to measure, so it is commonly ignored. Equally problematic is the objective measurement and comparison of losses and the acquisition of new quality capital with the change in cultural practices. "In order for markets of goods and services of implicit quality to progress, it must be supported by specialized institutions that would eliminate information distortions. Otherwise, markets will not emerge at all or will degrade due to the outflow of dissatisfied participants "[3, p. 115]. This problem is common in many cities, especially in metropolitan areas where there is increasing demand for a clear vision of prospects, a desire to receive the same clear quality signals. It is expert work that help to protect this area from low-profile enthusiasts and agents who, using the aforementioned "implicit quality" of cultural products, playing on consumer incompetence, their variety of tastes, fill the cultural space with low quality goods. The danger is exacerbated by the fact that if this trend continues, people will generally lose the ability to identify the quality and, consequently, the need for it. Cultural expertise can become one of the instruments of counteraction to the "business colonization of culture" [3, p.25], provided that it will function as an independent body, which must be impartial in terms of lobbying the temporary beneficial interests of certain economic entities, economic, socio-political, artistic and other spheres of activity.

The growth of social mobility is accompanied by the problematization of the processes of self-identification, 
inculturation and self-positioning in new environments and communities. The reference points for recognizing "one's" and "other's" are objects that people surround themselves with. The system of codes, their symbolic language, assimilated by the masses, are transformed into imitation strategies that allow to create a winning image. Visuals, stereotypes become more of a priority than true, genuine ones that require effort to learn. As a result, the predominance of externally rational, but in reality inferior, inactive lifestyles takes place [3, p. 366, 367]. Modernity is "sick" with the deterioration of selection in culture, the shift of balance in the direction of mass inquiry, which, in turn, is focused mainly on low quality unified products. There are many reasons for this phenomena. One of them is that "some cultural products that does not contain any great humanity or even a small individual innovation, but which is properly exhibited under the sign of art, can give rise to a strong reaction from the recipient... Experiences are born of imagination, memory of a human being,... her willingness and ability to aesthetize and spiritualize any object... People confuse the real and the fake "[3, p. 157 , 158]. Cultural expertise can be an indicator of cultural product quality, socio-economic and artistic activity, an element of support for quality cultural production and consumption. By contributing to the "exposure of cultural goods created just for the sake of money and surviving through misinformation" [3, p.336], it can become an influential one in reforming the urban cultural space, "in the face of demand for creative innovations designed for territorially dispersed groups" [ 3, p. 336].

For example, modern visual practices, street art in particular, have become an effective mechanism for creating a monotonous urban environment. Monumental murals, a variety of graffiti and media forms, LED art, green street art, public art offer the city residents a new language of interaction. Making intervention to the traditional traditional visual forms of communication, it become not only the way of creative expression, but also "places of sound of their voice" and "articulation of other voices", creating "effect of presence", involvement in the whole one [11]. The unique face of the city is revealed only in the presence of a holistic perception of the organization of its space. Urban architecture, both individual buildings and entire complexes, in any case (whether it is typical impersonal building or creative, unique, "living" space) is always a representation of the memory of the cultures, aesthetic models. The value of an innovation as an element of a figurative system of shaping the picture of the world can be much greater than its activity as an individual unit. Detection of such a semantic mean is possible due to the presence of perspective vision from an expert. This promising vision involves identifying the presence or the absence of the appropriate cultural context for the activity, its integration into the linguistic (symbolic) environment, and the perspective on the latest communication technologies, regarding the degree of coincidence of institutional, group and personal goals.

Conclusion. In the era of "rational chaos" one of the central problems of modern urban culture is the problem of consumer navigation. It is about the production and information "assets" of the urban population as creator and consumer. The cultural space of the modern city is characterized by the predominance of eclecticism, collage. It combines many different interests and needs of different populations. They are not always equal in a heterogeneous modern urban space, while tensely coexisting. Cultural expertise is an instance, transversal (penetrating) in its nature, which, taking into account cultural, discursive, sign- symbolic and other differences, passing through their bipolarity, particularity, finds the expert basis for their constructive interaction. The importance of such activities is constantly amplified in a situation of globalization, when cultural differences are smoothed, the boundaries between "one's" and "other's" are blurring, the individual is rigidly identified with one (own) cultural circle or the whole culture, and each individual space is increasingly diversified to specific segments and audiences [1].

Expert activities in the field of culture will "greatly optimize the process of urban planning, allowing to take into account the human factor on the level of general planning of urban structures", "to direct and build more expressive urban planning compositions that develop in space and time, taking into account their visual perception by man on the basis of a pre-developed scenario" [7]. Cultural expertise can be the transversal mechanism and tool of finding the optimal analytical evaluation of relationships, their intersections, depth structures, and the various kinds of chronotopes that are inherent in a modern city. It is a kind of humanitarian project, that space of rationality between different interests, needs, requests and actions of certain groups of the population, which is aimed at finding a certain common basis for their mutual penetration and complementarity, without losing their identity in the dynamics of creative sustainable selfdevelopment. The issue of cultural expert knowledge is a matter of optimizing the use of the urban cultural capital, removing restrictions on access to its resources. The value consequences of these actions, projects, practices will only emerge over time. Therefore, the ultimate "beneficiary" of cultural expertise, whatever it may be, are the next generations, their interests, the presence of humanity in an individual, who often do not take into account the modern market that shapes urban space.

\section{СПИСОК ВИКОРИСТАНИХ ДЖЕРЕЛ:}

1. Гафрарова Ю. Проект трансверсальной философии как разрешение дихотомии национального и универсального в общемировой философской традиции / Ю. Гафарова. [Електронний ресурс]. - Режим доступy: https://uchebnikfree.com/filosofiya-narodov-kniga/proekt-transversalnoyfilosofii-kak-27755.html

2. Доклад о человеческом развитии 2016. Человеческое развитие для всех и каждого. [Електронний ресурс]. - Режим доступу: http://hdr.undp.org/sites/default/files/HDR2016_RU_Overview_Web.pdf

3. Долгин А.Б. Экономика символического обмела / А. Б. Долгин. - М.: Прагматика культуры, Институт экономики культуры, 2007. - 640 с.

4. Индекс развития человеческого потенциала. [Електронний ресурс]. - Режим доступу: https://gtmarket.ru/ratings/human-developmentindex/human-development-index-info

5. Колесников А. Постмодерн и новое постметафизическое мышление: от трансмодернизма к трансверсальности / А. Колесников. [Електронний ресурс]. - Режим доступу: https://www.docme.su/doc/ 1509457/postmodern-i-novoe-postmetafizicheskoe-myshlenie-ot-transmo...

6. Корнилова К., Сарбитова И. Значимость индекса человеческого развития для макроэкономики / К. Корнилова, И. Сарбитова // Научное сообщество студентов XXI столетия. Экономические науки: сб. ст. по мат. XLIII междунар. студ. науч.-практ. конф. № 6(43), 2016. [Електронний ресурс]. - Режим доступу: URL: https://sibac.info/ archive/economy/6(43).pdf

7. Михайлов С. Дизайн современного города: комплексная организация предметно-пространственной среды: теоретико-методологическая концепция. Автореферат докт. диссерт. 17.00.06. - М. 2011 / С. Михайлов. [Електронний ресурс]. - Режим доступу: https://www.dissercat.com/content/dizain-sovremennogo-gorodakompleksnaya-organizatsiya-predmetno-prostranstvennoi-sredy-teore

8. Сеннет Р. Падение публичного человека / Р. Сеннет. - М.: Логос, 2002. $-424 \mathrm{c}$.

9. Стародубцева Л. В. Архітектура постмодернізму. Історія. Теорія. Практика / Л. В. Стародубцева - К.: Спалах, 1998. - 207 с.

10. Тараканова О. Зачем нужны публичные городские пространства и какими они должны бать / О. Тараканова. [Електронний ресурс]. Режим доступу: https://knife.media/public-spaces/

11. Фесенко Г. Естетика публічного простору міста в контексті філософрії суб'єкта творчості / Г. Фесенко. [Електронний ресурс]. - Режим доступу: http://www.apfs.in.ua/v10_2016/45.pdf 


\section{REFERENCES:}

1. Gafarova, Yu (2011). Proekt transversal'noj filosofii kak razreshenie dikhotomii naczional'nogo i universal'nogo $v$ obshhemirovoj filosofskoj tradiczii [The project of transversal philosophy as a resolution of the dichotomy of the national and universal in the global philosophical tradition]. Retrieved from https://uchebnikfree.com/filosofiya-narodov-kniga/proekttransversalnoy-filosofii-kak-27755.html.

2. Doklad o chelovecheskom razvitii 2016 (2016). Chelovecheskoe razvitie dlya vsekh i kazhdogo. [Human Development Report 2016. Human Development for Everyone and Everyone]. Retrieved from http://hdr.undp.org/sites/default/files/HDR2016_RU_Overview_Web.pdf.

3. Dolgin, A. B. (2007). Ekonomika simvolicheskogo obmena [The economy of symbolic exchange]. Moskow, Pragmatika kul'tury'.

4. Indeks razvitiya chelovecheskogo potencziala [Human Development Index] (2019). Retrieved from https://gtmarket.ru/ratings/humandevelopment-index/human-development-index-info.

5. Kolesnikov, A. (2010). Postmodern i novoe postmetafizicheskoe my'shlenie: ot transmodernizma $\mathrm{k}$ transversal'nosti [Postmodernism and the new postmetaphysical thinking: from transmodernism to transversality]. Retrieved from https://www.docme.su/doc/1509457/postmodern-i-novoepostmetafizicheskoe-myshlenie-ot-transmo...

6. Kornilova, K., Sarbitova, I. (2016) Znachimost' indeksa chelovecheskogo razvitiya dlya makroe'konomiki [The importance of the human development index for macroeconomics ]. Nauchnoe soobshhestvo studentov XXI stoletiya. E'konomicheskie nauki: sb. st. po mat. XLIII mezhdunar.stud. nauch.-prakt. konf. 6(43). Retrieved from https://sibac.info/archive/economy/6(43).pdf.

7. Mikhajlov, S. (2011). Dizajn sovremennogo goroda: kompleksnaya organizacziya predmetno-prostranstvennoj sredy': teoretikometodologicheskaya konczepcziya [The design of a modern city: the integrated organization of the subject-spatial environment: a theoretical and methodological concept]. Avtoreferat dokt. dissert. 17.00.06. Moskow. Retrieved from https://www.dissercat.com/content/dizain-sovremennogogoroda-kompleksnaya-organizatsiya-predmetno-prostranstvennoi-sredy-teore.

8. Sennet, R. (2002). Padenie publichnogo cheloveka. [The fall of a public man]. Moskow, Logos

9. Starodubtseva, L. (1998). Arkhitektura postmodernizmu. Istoriia. Teoriia. Praktyka [Architecture of postmodernism. History. Theory.Practice]. Kyiv, Spalakh.

10. Tarakanova, O. (2018) Zachem nuzhny' publichny'e gorodskie prostranstva i kakimi oni dolzhny' by't' [Why public urban spaces are needed and what they should be]. Retrieved from https://knife.media/public-spaces/.

11. Fesenko, H. (2016) Estetyka publichnoho prostoru mista v konteksti filosofii subiekta tvorchosti [Aesthetics of the city's public space in the context of the subject's philosophy of creativity]. Retrieved from http://www.apfs.in.ua/v10 2016/45.pdf.

Received Editorial Board 29.01.19

І. В. Живоглядова, канд. філос. наук, доц.

Київський національний університет імені Тараса Шевченка,

вул. Володимирська, 60, м. Київ, 01033, Україна

\section{ДОСЛІДНИЦЬКІ ПЕРСПЕКТИВИ КУЛЬТУРОЛОГІЧНОЇ ЕКСПЕРТИЗИ В КОНТЕКСТІ ФОРМУВАННЯ КУЛЬТУРНОГО ПРОСТОРУ МІСТА}

У статті в контексті формування культурного простору міста здійснюється аналіз спектра об'єктів та проблем, які можуть (I потребують) бути в якості предмета уваги експертної діяльності в сфері культури. Висновується, що в епоху "раціонального хаосу" одна $з$ центральних проблем сучасної міської культури - проблема споживацької навігації. Мова йде про виробничі та інформаційні "активи" міського населення в якості творця і споживача. Культурний простір сучасного міста характеризує переважання еклектики, колажності. У ньому переплітаються численні інтереси і потреби різних груп населення. Вони є не завжди рівноправними в гетерогенному сучасному міському просторі, напружено співіснуючи. Культурологічна експертиза - інстанція, трансверсальна (пронизуюча) за своїм характером, яка, враховуючи культурні, дискурсивні, знаково-символічні та ін. відмінності, проходячи крізь товщу їхньої біполярності, партикулярності, знаходить експертне підгрунтя для їхнього конструктивного співіснування через взаємозбагачення і взаємодоповнення. Питання культурологічного експертного знання розглядається в контексті оптимізації використання культурного капіталу міста, зняття обмежень доступу до його ресурсів, створення інструментів протидії "бізнес-колонізації культури".

Зазначається, що дієвим механізмом креативізації одноманітного міського середовища стали сучасні візуальні практики. Дослідження ґрунтується на розумінні того, що взаємодія просторової композиції міста, їі елементів, дизайн-форм, історичноархітектурного контексту не є лише потребою розвитку науково-теоретичного дискурсу. Планування міського простору, різноманітних елементів його ландшафту візуалізується в цілісне обличчя міста, яке, в свою чергу, є складовою картини світу мешканців міста. Якщо місто розглядати як складну багатофункціональну відкриту систему з цілою низкою проблем, які постійно осучаснюються, то розв'язання цих проблем неможливе без отримання об'єктивної інформації, яка б надавала знання щодо ступеня врахування, під час будь-якого втручання в організацію міського предметно-просторового середовища, "людського фактора", того, наскільки ці зміни, відповідаючи на нові потреби і уявлення про комфортне життя нових мешканців міста, кардинально впливають на ціннісну якість цього життя, наскільки задіяні нові технології "працюють" не тільки на економічну ефективність, на створення сприятливих умов для ведення бізнесу, але й корелюють, в якості гармонійного елемента, з інтересами людського розвитку на довгострокову перспективу. В сучасних умовах розвитку суспільства культурологічна експертиза і є репрезентантом соціальної затребуваності культурологічного знання.

Ключові слова: культурологічна експертиза, культурний простір міста, сучасні візуальні практики, культурний капітал.

И. В. Живоглядова, канд. филос. наук, доц.

Киевский национальный университет имени Тараса Шевченко,

ул. Владимирская, 60, г. Киев, 01033, Украина

\section{ИССЛЕДОВАТЕЛЬСКИЕ ПЕРСПЕКТИВЫ КУЛЬТУРОЛОГИЧЕСКОЙ ЭКСПЕРТИЗЫ В КОНТЕКСТЕ ФОРМИРОВАНИЯ КУЛЬТУРНОГО ПРОСТРАНСТВА ГОРОДА}

В статье в контексте формирования культурного пространства города проводится анализ спектра объектов и проблем, которые могут (и нуждаются) быть предметом внимания экспертной деятельности в сфере культуры. Вопрос культурологического экспертного знания рассматривается в контексте процессов оптимизации использования культурного капитала города, снятия ограничений доступа к его ресурсам, создания инструментов противодействия "бизнес-колонизации культуры". Утверждается, что культурологическая экспертиза может стать трансверсальным механизмом и средством нахождения оптимальной аналитической оценки взаимосвязей, их пересечений, глубинных структур, разного рода хронотопов, которые присущи современному городу.

Ключевые слова: культурологическая экспертиза, культурное пространство города, современные визуальные практики, культурный капитал. 